\title{
ANALISIS HASIL BELAJAR KIMIA SISWA YANG DIBELAJARKAN MENGGUNAKAN MODEL PROBLEM BASED LEARNING BERMEDIA POWERPOINT MELALUI PENDEKATAN SAINTIFIK PADA POKOK BAHASAN REDOKS
}

\author{
Ramlan Silaban $^{1)}$; Elysarani Br Tarigan ${ }^{2)}$; Irving Josafat Alexander ${ }^{3)}$ \\ 1. Program Studi Pendidikan Kimia, FMIPA, Universitas Negeri Medan, \\ Jl. Willem Iskandar Psr. V, Medan Estate, Indonesia, 20221 \\ 2.Program Studi Pendidikan Kimia, FMIPA, Universitas Negeri Medan \\ Jl. Willem Iskandar Psr. V, Medan Estate, Indonesia, 20221 \\ ${ }^{3 .}$ Program Magister Kimia, FMIPA Universitas Sumatera Utara \\ J1. Dr. Bioteknologi Kampus USU Medan
}

\begin{abstract}
This study aims to find out the chemistry learning outcomes of students with the completeness of the value of Minimum Completion Criteria (KKM), knowing the students 'social attitudes in the learning process, knowing the differences in learning outcomes, the correlation between students' social attitudes toward learning outcomes, and which models are most effectively used in learning models in giving a high contribution to student learning outcomes and students' social attitudes. The study was conducted on class X students of SMA 1 Tigapanah Karo Regency. The results showed that the percentage of students' completeness scores from experiment 1 was $75 \%$, experiment 2 and experiment 3 were $45.83 \%$. The percentage value of experimental 1 social attitudes which belong to the high category is $54.2 \%$ and which is categorized as quite $45.8 \%$. The value of students' social attitudes from experiment 2 which belong to the high category is $58.8 \%$ and those that are classified as sufficient categories are $41.2 \%$. The value of the students' social attitudes from experiment 3 which belong to the high category is $66.7 \%$, which is categorized as quite by $29.2 \%$, and which is classified as a category of less than $4.1 \%$. The difference in posttest values that experimental learning results 1 (73.13)> experimental class 2 (67.29)> experimental class 3 (66.88) and social attitudes of students in each class can be seen from the average score of students' social attitudes, namely (70.44)> experiment 2 (69.12)> experiment 3 (69.79). There is a correlation between social attitudes and learning outcomes in each class. Teaching with the Problem Based Learning model with powerpoint media through the most effective Scientific Approach is used in teaching to students as evidenced by the highest average learning outcomes of 73.13 and the average value of student learning outcomes is 70.44 .
\end{abstract}

Keywords: Problem Based Learning, Powerpoint, Scientific Approach, Redox.

\section{PENDAHULUAN}

Menurut Purwanto (2017 : 19), pendidikan berasal dari bahasa Yunani "paedagogie" yang terbentuk dari kata "pais" yang berarti anak dan "again" yang berarti membimbing. Dari arti kata itu maka dapat didefinisikan secara leksikal bahwa pendidikan adalah bimbingan / pertolongan yang 
diberikan pada anak oleh orang dewasa secara sengaja agar anak menjadi dewasa.

Melalui pendidikan, maka manusia harus belajar. Belajar merupakan proses manusia untuk mencapai berbagai macam kompetensi, keterampilan dan sikap. Kemampuan manusia untuk belajar merupakan karakteristik penting yang membedakan manusia dengan maklum hidup lainnya. Dapat juga diartikan belajar adalah usaha memperoleh kepandaian atau ilmu. Belajar ditandai dengan adanya perubahan tingkah laku (change behavior), perubahan perilaku relative permanent, perubahan tingkah laku tidak harus segera dapat diamati pada saat proses belajar sedang berlangsung (potensial), perubahan tingkah laku merupakan hasil latihan atau pengalaman, dan pengalaman atau latihan itu dapat memberi penguatan (Baharuddin dan Wahyuni, $2015: 13$ - 14).

Model Problem Based Learning (PBL) memberikan siswa kesempatan untuk mempraktekkan pemikiran kritis mereka, pembelajaran mandiri, diskusi dalam kelompok, dan berbagi pendapat antar siswa (Apriliadewi, 2017:17).

Ada beberapa alasan mengapa media pembelajaran dikembangkan antara lain sebagai variasi dalam pembelajaran, melatih pola pikir anak yang semula berpikir abstrak menjadi berpikir secara konkret, dan menarik ( Putra, 2013 : 3). Media komunikasi dalam dunia pendidikan memberikan kontribusi yang besar dalam kemajuan maupun peningkatatn mutu di suatu lembaga pendidikan. Dengan memakai media tersebut anak didik akan mudah mencerna dan memahami suatu pelajaran. Dengan demikian, melalui pendekatan ilmiah sistematis, dan rasional tujuan pendidikan dapat dicapai secara efektif dan efisien (Umar, 2013 : 128).

Berdasarkan observasi di SMA Negeri 1 Tigapanah yang telah menerapkan kurikulum 2013 mempunyai nilai Kriteria Ketuntasan Minimal (KKM) kimia sebesar 70. Kenyataannya pada data rekap nilai ujian semester masih banyak siswa yang belum mencukupi KKM kimia. Pokok bahasan Reaksi Oksidasi Reduksi (Redoks) merupakan materi kimia yang diberikan kepada siswa kelas X semester genap.

Beberapa penelitian yang relevan, terbukti dapat meningkatkan hasil belajar siswa, antara lain: Jufrina dan Utami (2016), menyatakan besarnya pengaruh penerapan model pembelajaran berbasis masalah terhadap keterampilan berpikir kritis kimia siswa adalah sebesar 5,5\% dan $87 \%$ siswa mencapai KKM dalam materi reaksi oksidasi. Pratiwi, dkk (2014), berdasarkan hasil penelitian dapat disimpulkan ketercapaian target pembelajaran yaitu $81,25 \%$ peserta didik mencapai KKM dalam pelaksanaan model pembelajaran Problem Based Learning (PBL) Pada Materi Redoks Kelas X SMA Negeri 5 Surakarta. Dan dalam penelitian Iswari (2016), pembelajaran menggunakan model Problem Based Learning berbasis literatur sains memberi pengaruh yang lebih baik terhadap prestasi siswa pada pokok bahasan redoks, yaitu mencapai 72,4 \% . Dari beberapa peneliti yang sudah ada, peneliti ingin melihat pengaruh penerapan model PBL dengan media Power Point terhadap hasil belajar kimia siswa SMA Negeri 1 Tigapanah. 
Berdasarkan latar belakang dan pemikiran tersebut, maka penulis tertarik untuk mengadakan penelitian yang berjudul "Analisis Hasil Belajar Kimia Siswa Yang Dibelajarkan Menggunakan Model Problem Based Learning Bermedia Powerpoint Melalui Pendekatan Saintifik Pada Pokok Bahasan Redoks".

\section{METODE PENELITIAN}

Penelitian ini dilakukan di SMA Negeri 1 Tigapanah, kelas X IPA semester genap tahun ajaran 2017 / 2018 sejak bulan Desember sampai Juni tahun 2018.

Populasi dalam penelitian ini adalah seluruh SMA di Kecamatan Tigapanah. Banyaknya sampel yang digunakan dalam penelitian ini adalah sebanyak 24 siswa dari tiap kelas yang mengambil peminatan IPA di kelas $\mathrm{X}$ SMA Negeri 1 Tigapanah. Pengambilan sampel dilakukan dengan teknik sampel purposive. Kehomogenan sampel dilihat dari: kesamaan hasil pretest, keikutsertaan dalam les privat, alat untuk mengakses internet, banyaknya buku kimia yang dimiliki.

Penelitian ini menggunakan Rancangan Acak Lengkap (RAL). Dalam melaksanakan penelitian ini melibatkan 3 perlakukan yang berbeda antara kelas eksperimen 1, kelas eksperimen 2, dan kelas eksperimen 3. Ketiga kelas diberikan pretest. Selanjutnya kelas eksperimen 1 dibelajarkan dengan model PBL menggunakan media powerpoint melalui pendekatan saintifik, eksperimen 2 dibelajarkan dengan media powerpoint melalui pendekatan saintifik, dan kelas eksperimen 3 dibelajarkan dengan pendekatan saintifik. Kemudian observer melakukan penilaian terhadap sikap sosial siswa. Dan selanjutnya dilakukan posttest.

Variabel bebas : Model Pembelajaran PBL dan Media powerpoint. Variabel terikat: Hasil belajar siswa (kognitif dan afektif) yang diberi perlakukan pada pokok bahasan redoks.

Instrumen penelitian ini adalah 2 yaitu instrumen penelitian Tes (yang telah memenuhi syarat : Validitas Tes, Reliabilitas Tes, Taraf Kesukaran, Daya Pembeda, dan Distruktor) dan instrumen Non-tes (Sikap Sosial Siswa).

Untuk menghitung nilai lembar observasi hasil belajar siswa digunakan rumus:

$$
\text { NilaiSikap }=\frac{\text { skor yang diperoleh }}{\text { skor maksimum }} \times 100
$$

Untuk mengelompokkan sikap sosial siswa dalam kategori kurang, cukup, dan tinggi (tabel 1) dapat ditentukan dari interval persen berikut:

Tabel 1. Persentase Nilai Sikap sosial Siswa

\begin{tabular}{|c|c|}
\hline Rentang Persentase & Kategori \\
\hline $0 \%-33 \%$ & Kurang \\
\hline $34 \%-67 \%$ & Cukup \\
\hline $68 \%-100 \%$ & Tinggi \\
\hline
\end{tabular}

Setelah selesai pemberian perlakuan serta post-test di setiap kelas eksperimen, maka data nilai hasil belajar siswa ditabulasi, kemudian dilakukan uji persyaratan analisis, yaitu Uji Normalitas, Uji Homogenitas, dan Uji Hipotesis (Uji Korelasi, dengan rumus Pearson Product Moment dan Uji Anava Satu Jalur).

\section{Hasil dan Pembahasan}

Setelah melakukan analisis instrumen, dalam instrumen tes dapat di simpulkan 
terdapat 20 soal yang dapat digunakan dalam penelitian. Dan instrumen non tes dapat digunakan dalam penelitian.

\section{Data Hasil Belajar Siswa}

Instrumen yang gunakan sama dengan instrumen saat pretest yaitu 20 soal pilihan berganda dengan lima pilihan jawaban (a, b, c, d, dan e). Pemberian pretest dan posttest dimasing - masing kelas eksperimen setelah diberikan perlakuan yang berbeda dengan materi yang sama. Hasil dari pretest dapat dilihat pada Tabel 2 - Tabel 3 dan Gambar 1 Gambar 3 posttest ketiga kelas eksperimen berikut :

Tabel 2. Data Hasil Pretest Siswa

\begin{tabular}{|c|c|c|c|}
\hline & Ekperimen 1 & Eksperimen 2 & Ekperimen 3 \\
\hline Nilai Minimum & 10 & 5 & 10 \\
\hline Nilai Maksimum & 40 & 40 & 50 \\
\hline Nilai rata - rata & 27,292 & 24,583 & 33,333 \\
\hline Variaans $\left(\mathrm{S}^{2}\right)$ & 62,998 & 93,297 & 138,406 \\
\hline
\end{tabular}

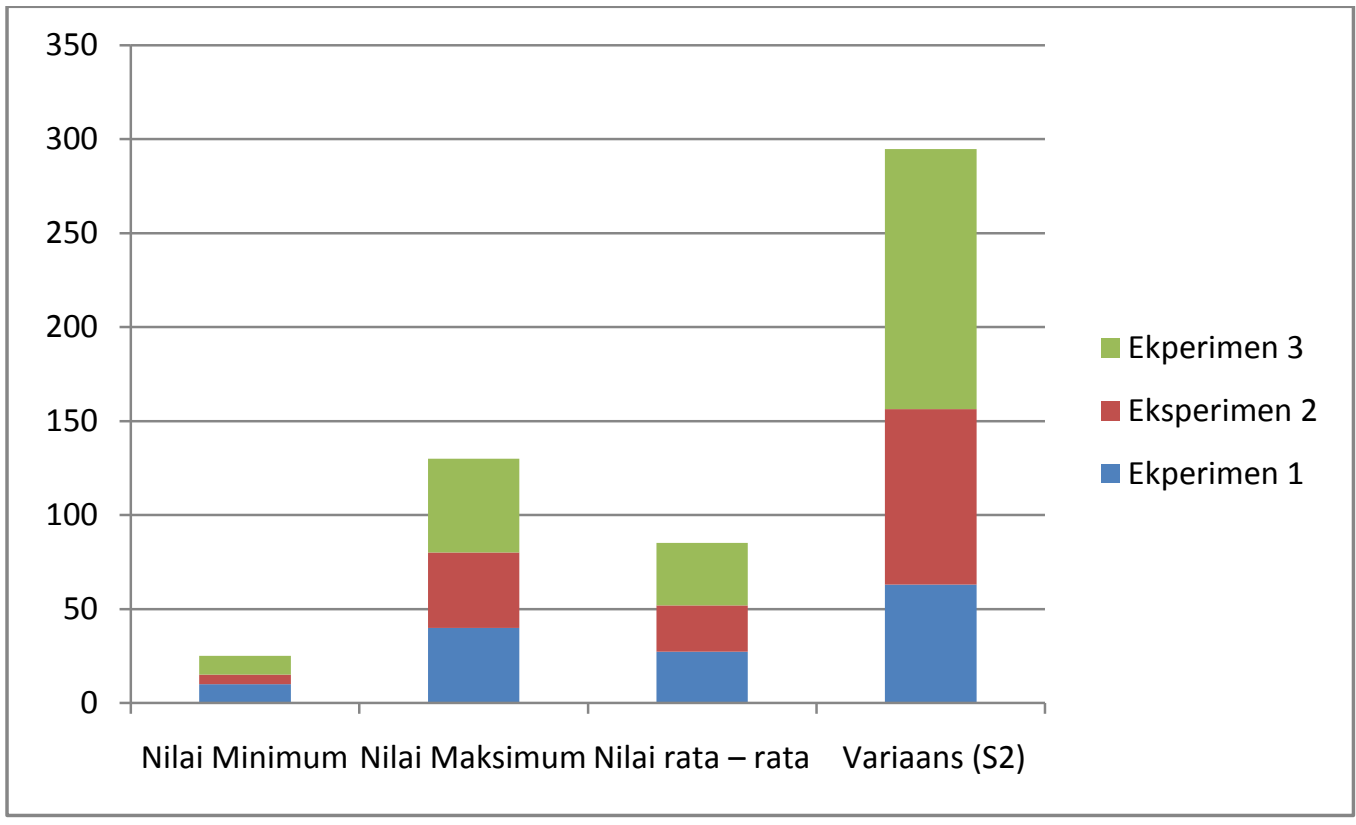

Gambar 1. Hasil Pretest Siswa

Tabel 3 Data Hasil Posttest Siswa

\begin{tabular}{|c|c|c|c|}
\hline & Ekperimen 1 & Eksperimen 2 & Ekperimen 3 \\
\hline Nilai Minimum & 50 & 50 & 50 \\
\hline Nilai Maksimum & 90 & 80 & 80 \\
\hline Nilai rata - rata & 73,125 & 67,292 & 66,875 \\
\hline Variaans (S ${ }^{2}$ ) & 103,940 & 60,824 & 53,940 \\
\hline Jumlah Nilai Siswa Yang & $\begin{array}{c}18 \text { Siswa } \\
\text { Tuntas KKM }\end{array}$ & $\begin{array}{c}11 \text { Siswa } \\
(75 \%)\end{array}$ & 11 Siswa \\
$(45,83 \%)$ & $(45,83 \%)$ \\
\hline
\end{tabular}




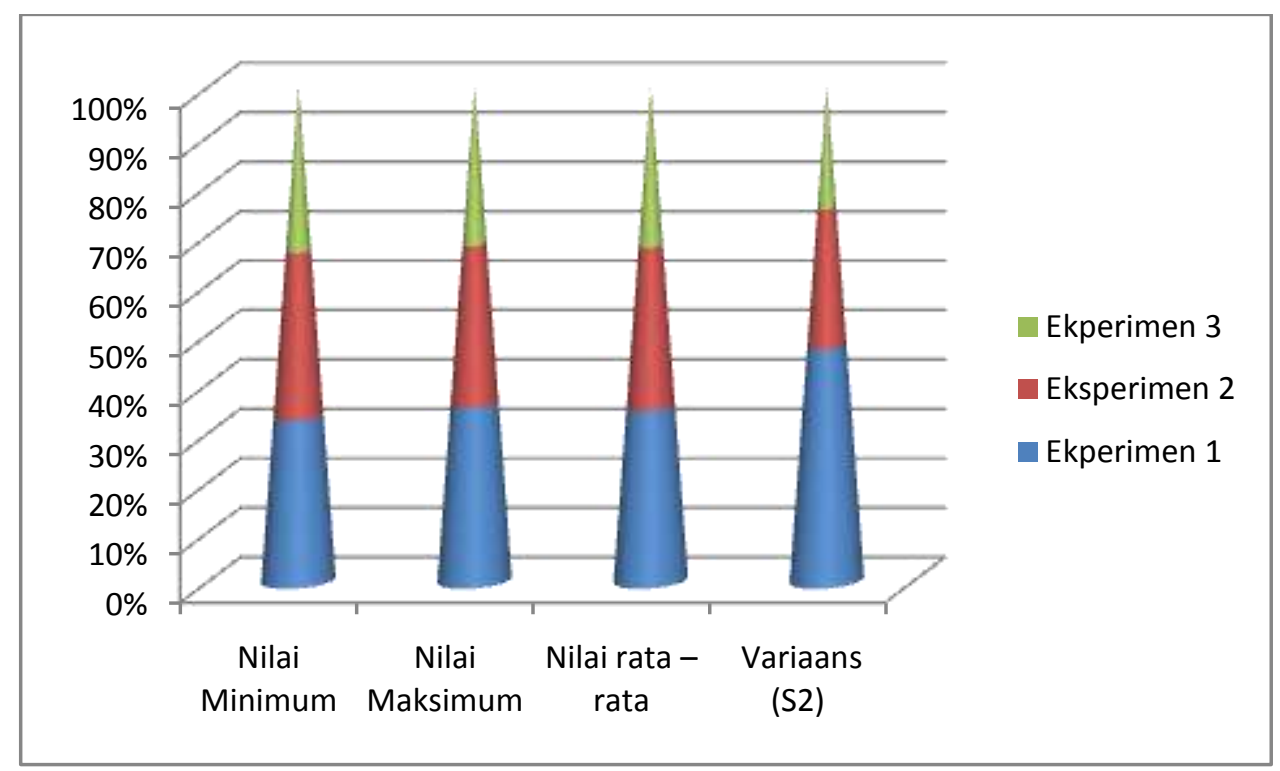

Gambar 2. Hasil Posttest Siswa

\section{Data Sikap Sosial Siswa}

Instrumen yang gunakan yaitu instrumen non tes. Instrumen non tes di gunakan saat dilakukan penilain sikap sosial siswa saat proses pembelajaran di lakukan di dalam masing- masing kelas eksperimen. Dari kelas eksperimen 1 terdapat $54,2 \%$ kedalam kategori tinggi dan 45,8 \% kategori cukup.
Dari kelas eksperimen 2 terdapat 58,3 \% kedalam kategori tinggi dan 41,2 \% kategori cukup. Dari kelas eksperimen 3 terdapat 66,7 $\%$ kedalam kategori tinggi dan 29,2 \% kategori cukup, dan 4,1\% kategori kurang. Hasil dari sikap sosial ketiga kelas eksperimen dapat dilihat di lihat pada tabel 4 dan Gambar 3 berikut

Tabel 4. Data Hasil Sikap Sosial Siswa

\begin{tabular}{|c|c|c|c|}
\hline & Ekperimen 1 & Eksperimen 2 & Ekperimen 3 \\
\hline Nilai minimum & 50 & 50 & 25 \\
\hline Nilai Maksimum & 93,75 & 90,53 & 87,5 \\
\hline Nilai rata - rata & 70,44 & 69,19 & 69,79 \\
\hline Jumlah Siswa yang Sikap & 13 Siswa & 14 Siswa & 16 Siswa \\
Sosial Kategori Tinggi & $(54,2 \%)$ & $(58,8 \%)$ & $(66,7 \%)$ \\
\hline Jumlah Siswa yang Sikap & 11 Siswa & 10 Siswa & 7 Siswa \\
Sosial Kategori Cukup & $(45,8 \%)$ & $(41,2 \%)$ & $(29,2 \%)$ \\
\hline Jumlah Siswa yang Sikap & - & - & 1 Siswa \\
Sosial Kategori Kurang & & & $(4,1 \%)$ \\
\hline
\end{tabular}




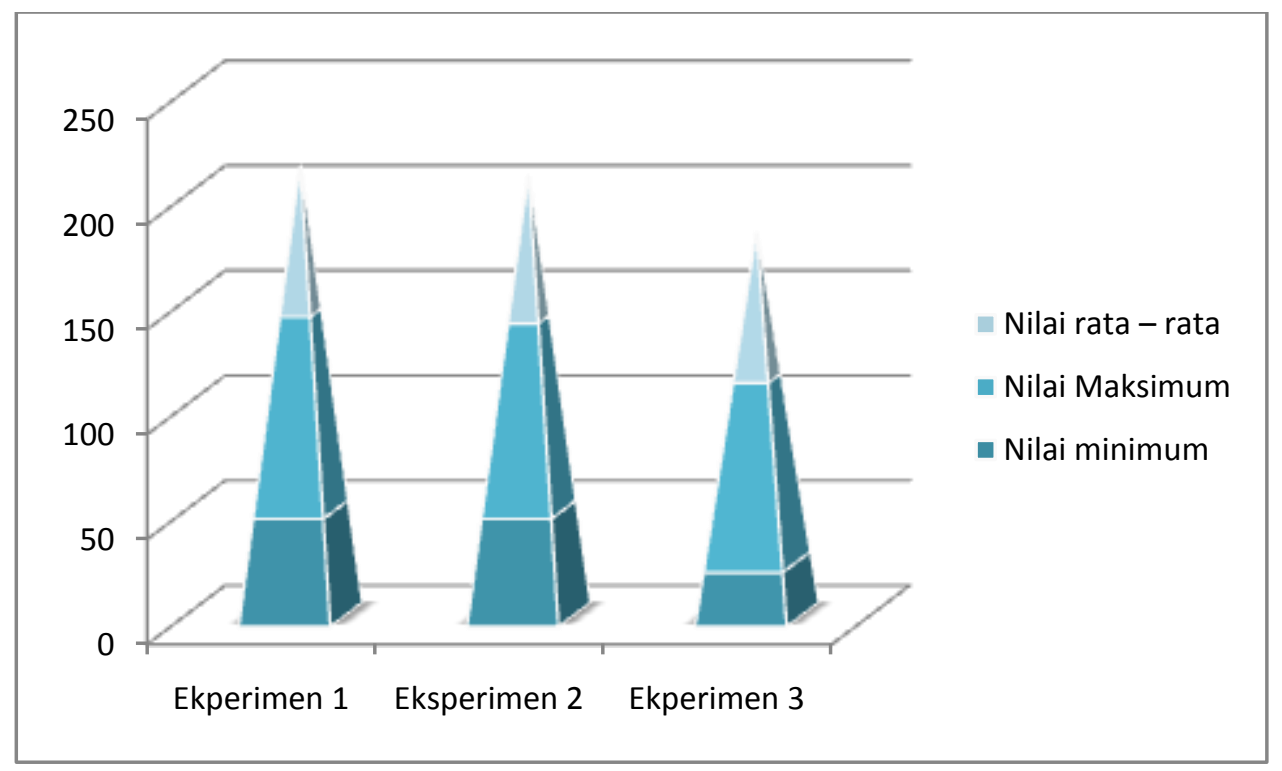

Gambar 3. Hasil Sikap Sosial Siswa

Dalam uji persyaratan analisa data maka data tersebut normal, dimana signifikansinya lebih besar dari 0,05 dan Pengujian homogenitas dilakukan pada data posttest dari ketiga kelas eksperimen. Data dikatakan memiliki varian yang sama (homogeny) jika nilai sig > 0,05. Hasil analisis homogenitas data posttest dari ketiga kelas eksperimen memiliki varian yang sama dengan taraf signifikansi $0,272>0,055$ yang bersifat

\section{homogen.}

\section{Uji Korelasi}

Pengujian hipotesis diuji dengan menggunakan software IBM SPSS Statistic 22. Hasil pengujian berdasarkan data hasil belajar dan sikap siswa untuk kelas eksperimen 1, eksperimen 2, dan eksperimen 3 dapat di lihat pada Tabel 5 berikut :

Tabel 5. Analisis Data Uji Korelasi

\begin{tabular}{|c|c|c|c|c|}
\hline No & Kelas & r hit & r tabel & Keterangan \\
\hline 1 & Eksperimen 1 & 0,940 & 0,404 & Ha diterima \\
\hline 2 & Eksperimen 2 & 0,547 & 0,404 & Ha diterima \\
\hline 3 & Eksperimen 3 & 0,699 & 0,404 & Ha diterima \\
\hline
\end{tabular}

Pada kolom ekperimen 1 diperoleh $\mathrm{r}$ hitung sebesar 0,940 dan nilai $r$ tabel sebesar 0,404. Karena nilai $r$ hit $>\mathrm{r}$ tabel maka Ho ditolak, dan Ha diterima, sehingga dapat di simpulkan bahwa ada kolerasi yang signifikan antara sikap sosial siswa terhadap hasil belajar 
(C1-C4) siswa dalam pembelajaran yang diajarkan menggunakan model Problem Based Learning dengan media powerpoint melalui Pendekatan Saintifik.

Pada kolom ekperimen 2 diperoleh $r$ hitung sebesar 0,547 dan nilai $r$ tabel sebesar 0,404. Karena nilai $r$ hit $>r$ tabel maka Ho ditolak, dan Ha diterima, sehingga dapat di simpulkan bahwa ada kolerasi yang signifikan antara sikap sosial siswa terhadap hasil belajar (C1-C4) siswa dalam pembelajaran menggunakan media powerpoint Melalui Pendekatan Saintifik.

Pada kolom ekperimen 3 diperoleh $\mathrm{r}$ hitung sebesar 0,699 dan nilai $r$ tabel sebesar 0,404. Karena nilai $r$ hit $>r$ tabel maka Ho ditolak, dan Ha diterima, sehingga dapat di simpulkan bahwa ada kolerasi yang signifikan

antara sikap sosial siswa terhadap hasil belajar (C1-C4) siswa dalam pembelajaran menggunakan Pendekatan Saintifik.

\section{Uji Anava Satu Jalur}

Hipotesis alternatif (Ha) adalah ada perbedaan hasil belajar kimia siswa antara yang diberi pengajaran dengan model Promblem Based Learning (PBL) bermedia powerpoint melalui pendekatan saintifik, dengan media powerpoint melalui pendekatan saintifik, dan melalui pendekatan saintifik. Pengujian hipotesis menggunakan uji anava satu jalur dengan kriteria $\alpha=0,05$. Hasil analisis uji hipotesis dapat dilihat pada Tabel 6 berikut:

Tabel .6. Hasil Anava Satu Jalur

\begin{tabular}{|l|r|r|r|r|r|}
\hline & \multicolumn{1}{|c|}{$\begin{array}{c}\text { Sum of } \\
\text { Squares }\end{array}$} & Df & Mean Square & F & Sig. \\
\hline Between Groups & 586,111 & 2 & 293,056 & 4,020 &, 022 \\
Within Groups & 5030,208 & 69 & 72,902 & & \\
Total & 5616,319 & 71 & & & \\
\hline
\end{tabular}

Dapat dilihat dari tabel diatas bahwa $\mathrm{F}$ hitung sebesar 4,020 > dari F tabel sebesar 2, 014 yang berarti $\mathrm{H}_{0}$ ditolak dan $\mathrm{H}_{\mathrm{a}}$ diterima. Melalui uji Tukey dapat dilihat bahwa rata-rata nilai kelas eksperimen yang menggunakan model PBL dengan media powerpoint melalui Pendekatan Saintifik lebih tinggi dibanding dengan powerpoint melalui Pendekatan Saintifik dan melalui Pendekatan Saintifik.
Jadi, kesimpulannya adalah $\mathrm{H}_{\mathrm{a}}$ diterima dan $\mathrm{H}_{0}$ ditolak dengan keterangan sebagai berikut:

Ha : Ada perbedaan hasil belajar kimia siswa antara yang diberi pengajaran dengan model PBL bermedia powerpoint melalui pendekatan saintifik, dengan media powerpoint melalui pendekatan saintifik, dan melalui pendekatan saintifik. 
Ho : Tidak ada perbedaan hasil belajar kimia siswa antara yang diberi pengajaran dengan model PBL bermedia powerpoint melalui pendekatan saintifik, dengan media powerpoint melalui pendekatan saintifik, dan melalui pendekatan saintifik Uji Tukey (Tabel 7) sebagai berikut:

Tabel 7.Hasil Uji Tukey Menggunakan SPSS-22

\begin{tabular}{|c|c|c|c|c|c|c|}
\hline \multirow[b]{2}{*}{ (I) $\mathrm{KE}$} & \multirow[b]{2}{*}{ (J) KE } & \multirow{2}{*}{$\begin{array}{c}\text { Mean } \\
\text { Difference (I- } \\
\mathbf{J})\end{array}$} & \multirow[b]{2}{*}{ Std. Error } & \multirow[b]{2}{*}{ Sig. } & \multicolumn{2}{|c|}{ 95\% Confidence Interval } \\
\hline & & & & & Lower Bound & Upper Bound \\
\hline \multirow[t]{2}{*}{ EKS1 } & EKS2 & 5,833 & 2,465 &, 053 &,- 07 & 11,74 \\
\hline & EKS3 & $6,250^{*}$ & 2,465 &, 036 &, 35 & 12,15 \\
\hline \multirow[t]{2}{*}{ EKS2 } & EKS 1 & $-5,833$ & 2,465 & 053 & $-11,74$ & 07 \\
\hline & EKS3 &, 417 & 2,465 & ,984 & $-5,49$ & 6,32 \\
\hline \multirow[t]{2}{*}{ EKS3 } & EKS1 & $-6,250^{*}$ & 2,465 & 036 & $-12,15$ &,- 35 \\
\hline & EKS2 &,- 417 & 2,465 & ,984 & $-6,32$ & 5,49 \\
\hline
\end{tabular}

*. The mean difference is significant at the 0.05 level.

Berdasarkan Tabel 7 Uji Tukey, dapat dilihat bahwa output perbandingan hasil belajar siswa untuk kelas eksperimen 1 (menggunakan PBL dengan media Power Point melalui Pendekatan Saintifik) dan kelas eksperimen 2 (dengan media Power Point melalui Pendekatan Saintifik) dengan signifikan >0,05 $(0,053>0,05)$ yang berarti kedua media tersebut memiliki kesamaan dalam perbandingan hasil belajar (Eksperimen 1 = Eksperimen 2). Demikian juga dengan output perbandingan hasil belajar siswa untuk kelas eksperimen 2 (menggunakan media Power Point melalui Pendekatan Saintifik) dan kelas eksperimen 3 (dengan Pendekatan Saintifik) dengan signifikan >0,05 (0,984 > $0,05)$ yang berarti kedua media tersebut memiliki kesamaan dalam perbandingan hasil belajar (Eksperimen 2 = Eksperimen 3 ). Hasil belajar pada eksperimen 3 (melalui pendekatan saintifik) lebih rendah dibandingkan eksperimen 1 (menggunakan PBL dengan media Power Point melalui Pendekatan Saintifik) dan eksperimen 2 (dengan media Power Point melalui Pendekatan Saintifik) dengan rata-rata nilai hasil belajar 73,13 (eksperimen 1), 67,29 (eksperimen 2), 66,88 (eksperimen 3) atau eksperimen $1>$ eksperimen $2>$ eksperimen 3 .

\section{SIMPULAN DAN SARAN}

\section{A. SIMPULAN}

1. Nilai sikap sosial siswa, maka diperoleh persentasi nilai sikap sosial eksperimen 1 yang tergolong ke kategori tinggi sebesar $54,2 \%$ dan yang tergolong kategori cukup 
sebesar $45,8 \%$. Nilai dari sikap sosial siswa dari kelas eksperimen 2 yang tergolong ke kategori tinggi sebesar 58,8 $\%$ dan yang tergolong kategori cukup sebesar $41,2 \%$. Nilai dari sikap sosial siswa dari kelas eksperimen 3 yang tergolong ke kategori tinggi sebesar 66,7 $\%$, yang tergolong kategori cukup sebesar $29,2 \%$, dan yang tergolong kategori kurang sebesar $4,1 \%$.

2. Terdapat perbedaan hasil belajar siswa yang diberi pengajaran dengan model Problem Based Learning dengan media powerpoint melalui Pendekatan Saintifik, model pengajaran dengan media powerpoint melalui Pendekatan Saintifik, dan model pengajaran dengan Pendekatan Saintifik . Uji tukey menunjukkan bahwa hasil belajar kelas eksperimen $1(73,13)$ > kelas eksperimen $2(67,29)>$ kelas eksperimen $3(66,88)$.

3. Terdapat perbedaan sikap sosial siswa yang diberi pengajaran dengan model Problem Based Learning dengan media powerpoint melalui Pendekatan Saintifik, model pengajaran dengan media powerpoint melalui Pendekatan Saintifik, dan model pengajaran dengan Pendekatan Saintifik . Terlihat dari nilai rata - rata sikap sosial siswa, yaitu $(70,44)>$ kelas eksperimen $2(69,12)>$ kelas eksperimen 3 $(69,79)$. Terdapat korelasi antara sikap sosial siswa terhadap hasil belajar siswa yang diajarkan dengan model Problem Based Learning dengan media powerpoint melalui Pendekatan Saintifik, $r$ hit $>r$ tabel $(0,940>0,404)$.
4. Terdapat korelasi antara sikap sosial siswa terhadap hasil belajar siswa yang diajarkan dengan menggunakan media powerpoint melalui Pendekatan Saintifik, $r$ hit $>r$ tabel $(0,547>0,404)$. Terdapat korelasi antara sikap sosial siswa terhadap hasil belajar siswa yang diajarkan melalui Pendekatan Saintifik, $r$ hit $>r$ tabel $(0,699$ $>0,404)$.

\section{B. SARAN}

1. Bagi guru dan calon guru, disarankan menerapkan model pembelajaran Problem Based Learning dengan media powerpoint melalui Pendekatan Saintifik sebagai salah satu alternatif dalam melakukan pengajaran disekolah.

2. Bagi peneliti selanjutnya, disarankan lebih memperhatikan kelemahan model pembelajaran ini serta dapat mengkolaborasikan model pembelajaran ini dengan media yang sesuai.

3. Peneliti selanjutnya diharapkan dapat melanjutkan penelitian dengan topik yang sama, agar hasil penelitian ini dapat bermanfaat sebagai penyimbang teori, khususnya dalam memilih model, media, dan pendekatan yang tepat dalam pengajaran di dalam kelas.

\section{DAFTAR PUSTAKA}

Apriliadewi., (2017), An Analysis Of The Implementasi Of Problem Based Learning In Learning English At The XI Grade Sciense Class Of SMA Negeri 1 Singaraja In The Academic Year 
2015/2016, International Journal Of

Language and Literature, Vol 1(1) :1-8.

Baharuddin, H dan EN. Wahyuni., (2015),

Teori Belajar Dan Pembelajaran, Ar-

Ruzz Media, Yogyakarta.

Iswari, Ni, Nengah, Dian., (2016), Pengaruh

Model Problem Based Learning

Berbasis Literatur Sains Terhadap

Prestasi Belajar Kimia Materi Pokok

Reaksi Redoks Pada Siswa Kelas X

SMAN 1 Lingsar Timur Tahun

Pelajaran 2015/1016, Skripsi, FIP,

Universitas Mataram, Mataram.

Jufrina, Yesi., dan Lisa Utami., (2016),

Pembelajaran Berbasis Masalah Untuk

Meningkatkan Berpikir Kritis Siswa

Pada Materi Reaksi Redoks, Jurnal

Tadris Kimiya, Vol 1(2) : 59-63.

Pratiwi, Yussi., Tri Redjeki., dan Mohammad

Masykuri., (2014), Pelaksanaan Model
Pembelajaran Problem Based Learning (PBL) Pada Materi Redoks Kelas X SMA Negeri 5 Surakarta Tahun Pelajaran 2013/2014, Jurnal Pendidikan Kimia (JPK), Vol 3(3) : 40-48.

Purwanto., (2017). Evaluasi Hasil Belajar, Pustaka Belajar, Yogyakarta.

Putra, Fu'an Widyarsa., (2013), Model Pembelajaran Langsung Bermedia Tagram Terhadap Hasil Belajar Geometri Pada Anak Berkesulitan Belajar, Skripsi, FIP, Universitas Negeri Semarang, Semarang.

Umar., (2013), Media Pendidikan: Peran dan Fungsi dalam Pembelajaran, Jurnal Tarbawiyah, Vol 10 ( 2 ) :126-141. 